\title{
Hazards Faced by Colonial Birds
}

\author{
by C. Stuart Houston, Saskatoon
}

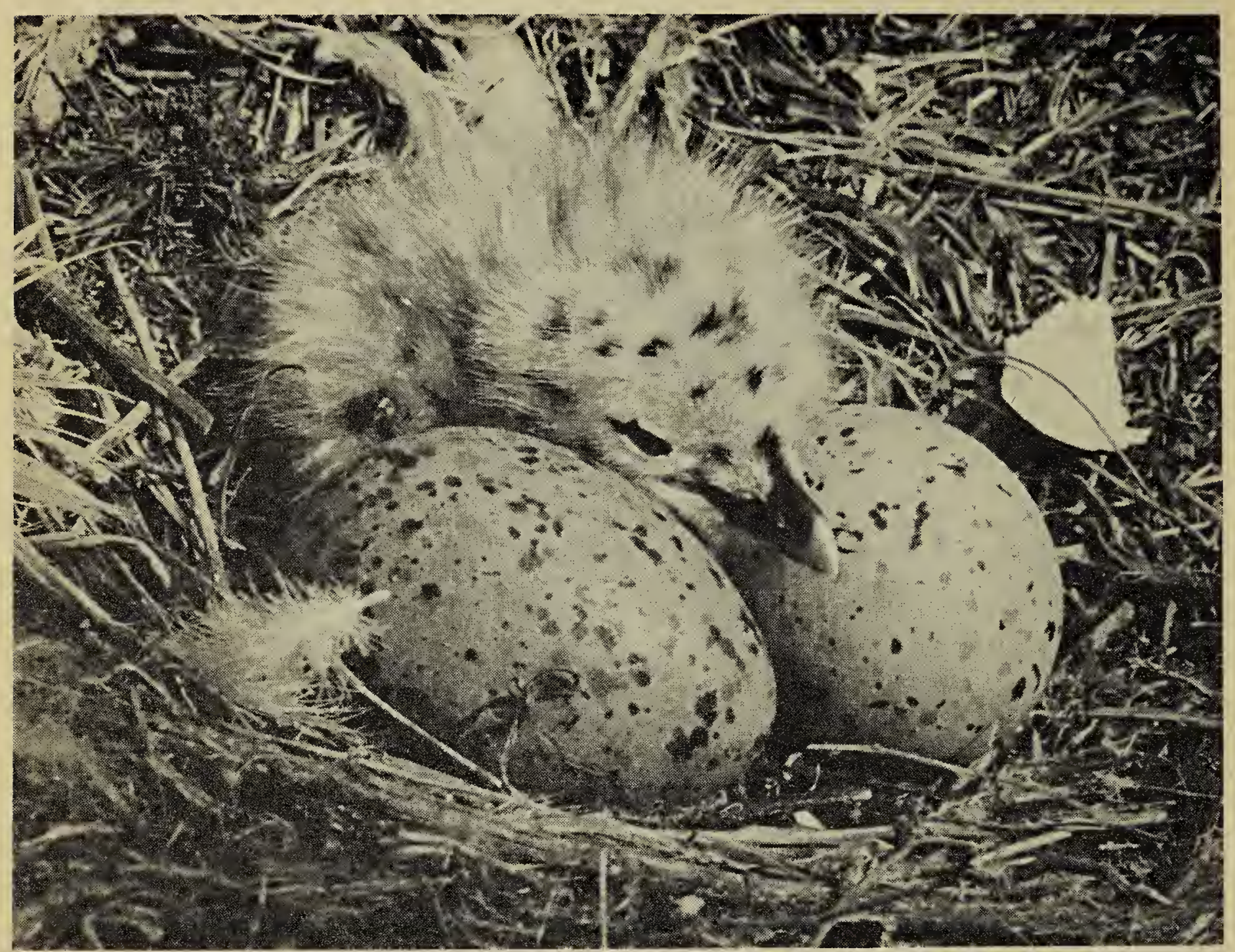

Colifornia Gull, a few hours old.

Photo by $\mathrm{H}$. Dommasch.

I have been quite impressed by the special difficulties faced by colonial birds, as I have visited them for banding purposes in the past ten years, from flood conditions through to drought. Their nesting habitat requirements are ver̂y specialized, for they require islands on large lakes. They are very vulnerable to the changing water levels which fluctuate between wide extremes on the prairies. Since they cannot tolerate much human visitation, their choice of nesting sites is becoming more restricted. Thompson, referring to the White Pelican, said in 1932 that Saskatchewan presented "the most favorable conditions of any region within its breeding range"; yet even here they appear in a somewhat precarious position.

It might be of interest to record the changing status of some of the Saskatchewan colonies of pelicans, cormorants and gulls that I have visited.

Last Mountain Lake was traditionally one of the best-known nesting sites of colonial birds. Here the late Reuben Lloyd of Davidson banded ntany cormorants in the late 1920's and 1930's. Here Fred Bard made his outstanding movie, "The Pelicans of Last Mountain"-and I understand from Fred that pelicans nested regularly at the north end of the lake, opposite Imperial Beach, up to and including 1952.

My first visit to the north end of Last Mountain Lake was in 1953. The lake rose several feet during the latter half of June, flooding the usual nesting sites, and the pelicans did not nest at all that year. Some cormorants belatedly attempted to nest at a new site twenty miles south on the west shore, opposite Penzance, where on June 26 there were 25 nests with 
eggs, 11 nests with live young and 5 with dead young. On August 1, the water level was up a further ten inches and most of that island was submerged - but there were 35 new cormorant nests with eggs on the highest ground!

In 1954, the cormorants had two successful colonies: the one begun the previous year on the west shore opposite Penzance, where I banded 85 young on July 19; the other, on the east shore across from Imperial Beach, where 71 were banded on July 24. Fifteen pelicans were banded at the latter location (a rather poor success from the 28 nests there on June 23) and this was the last known successful nesting of pelicans on the lake.

In 1955 , the cormbrant colony east of Penzance was thriving, though the island used previously was completely under water. The birds had moved a half mile north and a bit west to a new island - the highest part of what for years had been a cultivated field. The 90 nests present on: June 20 produced 144 young to band on July 16.

In 1956, water levels were dropping again and by the middle of July the 1955 nesting site was separated from the mainland only by a grassy area with water a few inches deep. Although readily accessible to mammalian predators from the mainland, 181 young cormorants were banded.

In 1957, the site of the 1955 and 1956 colonies was again dry land. The gulls, which had nested near the cormorants each year, moved back to their 1954 site. Only eight cormorant nests were present on June 24 .

In 1958 , there were again about 500 gull nests (95 per cent Ring-billed and 5 per cent California), but only five cormorant nests.

No cormorant nests could be located on Last Mountain Lake in 1960 or 1961.

Crana Lake was visited by Steve Mann on May 18, 1958, when an island near the south shore contained 256 pelican nests, 87 cormorant nests, 428 gull nests and 58 Common Tern nests.

When Steve Mann took me to this island for the first time on June 23, 1960 , we found a 1 ather desolate sight - the bodies of nearly 1000 recently dead young gulls were found on the island. However, a roughly equal number of healthy-looking young gulls had survived. Two days previously, on the evening of June $21 \mathrm{st}$, there had been a sudden downpour of $1 \frac{1}{4}$ " of rain and it is presumed that half the young gulls had in some way perished as a result of this. This gull colony was predominately Californias, with only a few Ring-bills. There were about 200 young pelicans and over 150 young cormorants, apparently thriving.

On June 27, 1961, water levels were down greatly and only a narrow channel of shallow muddy water separated the island from the mainland. About 200 young cormorants and 100 young pelicans were present, but there were no active gull nests. At the west end of the island was a rather smal] group of dead downy gulls, obviously dead for weeks. Mr. James, the neighboring rancher, informed us that a hail storm had occurred on June 4. We also speculated whether skunks or weasels might have crossed the shallow water to destroy the gulls without molesting the larger pelicans and cormorants.

Quill Lake was visited by John F. Ferry in July, 1910. He found 750 to 1000 young pelicans and nearly 300 young cormorants on an island at the south end of Big Quill Lake. Many adrit birds were seen flying in the direction of Last Mountain Lake each evening and Ferry believed they were feeding there. J. A. M. Patrick of Yorkton visited this colony in the 1920's and Fred Bradshaw of the Museum visited an island off the west shore of Big Quill in 1931 and reported 2000 adult pelicans and over 1000 young.

During the Second World War, the Quill Lakes were used as a bombing practice range for planes based on the nearby Dafoe air station. The pelicans and cormorants deserted the lake at this time. It is not certain when these colonies were re-established, but I believe their increasing size may have been coincident with the decreasing size of the colonies at Last Mountain Lake.

In 1956, I visited an island in the western end of Little Quill Lake (actually the connection between the two Quill Lakes, sometimes called "Middle Quill" or "Muddy Lake"). 
Here there was a small colony of Ring-billed Gulls together with 52 young cormorants and 1.9 young pelicans.

In 1957, this colony was larger, with 70 young cormorants and 100 young pelicans. A mile to the south, on a narrow-necked peninsula (recently an island) was an apparently new colony of at least 220 young pelicans.

In 1958 , both of these areas were deserted due to falling water levels, and another colony with 160 young pelicans was located on an island at the south end of Little Quill Lake, six miles north of Mozart. Seven Great Blue Heron nests were located in low trees, six to ten feet high, beside the colony. The farmer nearby said that the pelicans had been nesting there since about 1955.

In 1959, this area too became part of the mainland. No pelican colonies were located in 1959 or 1960 , but it was presumed that they were somewhere on Big Quill.

In 1961, water levels of the Quill Lakes deteriorated drastically _ so that the shoreline of the northeast corner of Big Quill receded one mile and "Middle Quill" dried up entirely. A survey on foot of the likeliest portion of Big Quill - the northeast corner - was unsuccessful and in desperation on July 5 th I chartered a light plane to fly me over the Quill Lakes to locate the nesting site of the pelicans. One flock of 30 pelicans were seen in flight, but a careful search of the entire shoreline showed that all previous islands with vegetation were now part of the mainland. The new low islands that had appeared were too low and offered no cover. Obviously no pelicans or cormorants nested on the Quill Lakes in 1961.

Manito Lake, south of Neilburg, had 300 nesting pairs of pelicans when J. A. Munro visited it in June 1921. According to Bradshaw, they left this lake during the drought years of 1930 or 1931 .

S. R. Belcher and I boated around this large saline lake on June 25, 1958 and could find no evidence of colonial birds nesting.

Dore Lake had over 100 young pelicans and over 500 young cormor- ants when I visited it in July 1956. The conservation officer informed me that local ranchers were in the habit of taking boatloads of eggs from these colonies to feed their mink, rationalizing that the fish-eating birds were harmful to the fishing interests on the lake. Since then, new roads and new resorts have been built, the major resort being just opposite the island I visited. I understand that the colony has decreased in size.

Redberry Lake, where 150 to 200 young pelicans are raised yearly, may soon be in danger owing to the increasing use of the lake as a resort. The only "safe" lake in southern Saskatchewan, with a good-sized island, rarely visited by humans, is old Wives Lake. Further north, Suggi Lake (northwest of Cumberland House) and Lavalee Lake (at the north end of Prince Albert National Park) are still relatively unmolested.

With better roads, bigger boats and motors, and an increasing number of people visiting all of these lakes in recent years, one can visualize an increasing problem in years to come. Already it appears that no portion of Last Mountain Lake is remote enough to allow pelicans and cormorants to nest successfully. It is not unusual to find recently empty beer battles in the middle of a gull colony, offering evidence of recent disruptive visits by boaters.

Pelicans and cormorants particularly cannot tolerate human molestation. A short exposure to the midday sun will kill a small naked cormorant or pelican. When the pelicans are frightened from their nests, the brazen California Gull takes advantages of this opportunity to break open and suck the pelican eggs. Eggs may be rolled from their nests by the hasty flight of the parents.

Young pelicans when frightened collect in groups called "pods" and the weaker ones may easily be trampled to death.

We cannot keep people from these lakes, but we should work for laws preventing people from setting foot on colonial islands in the nesting season. It would be difficult to enforce, but I would like to see boats prohibited from waters within half a mile of such islands. The hour is already late - but the picturesque 


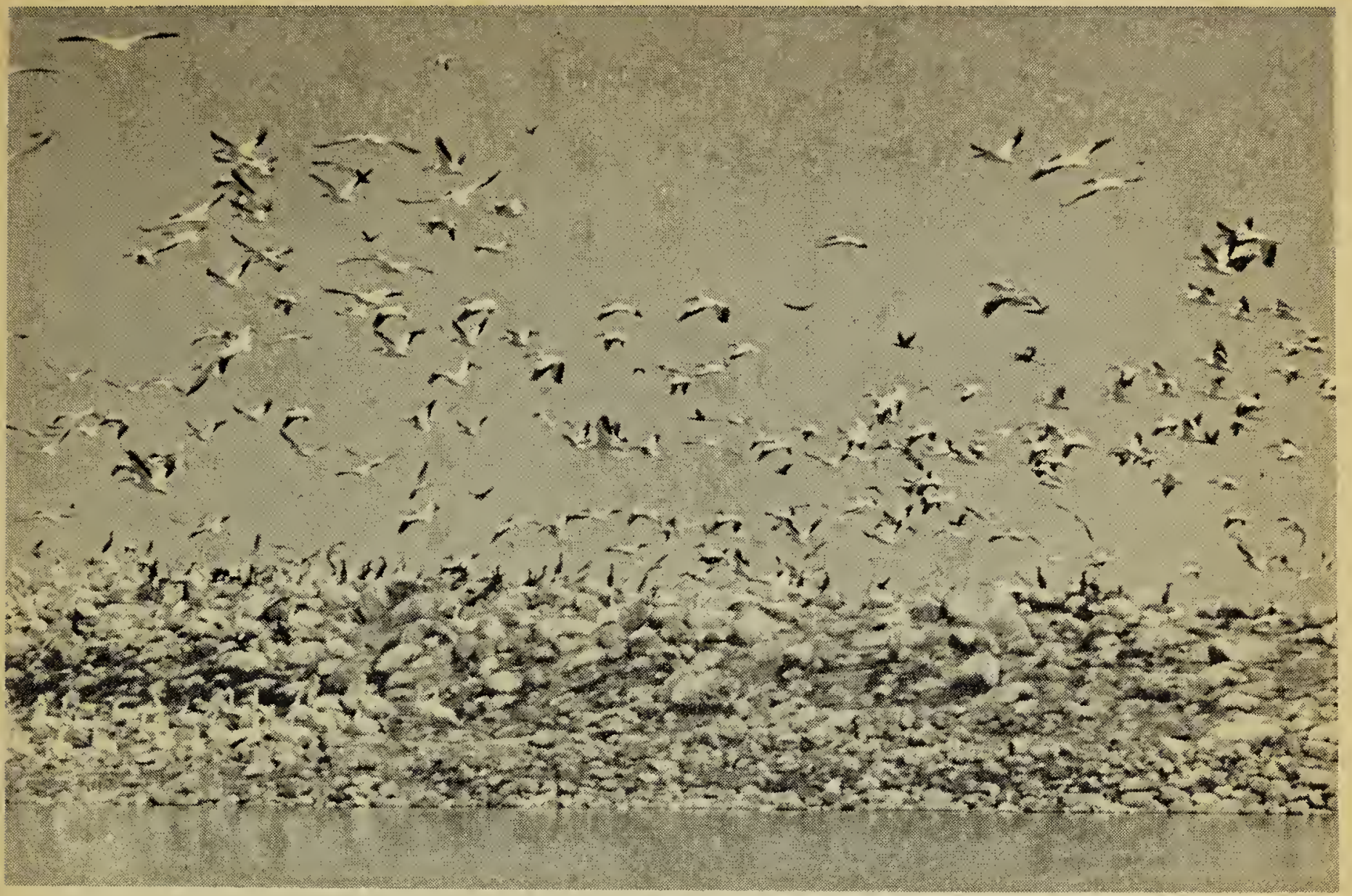

Photo by Fred G. Bard.

Colony of pelicans and cormorants at Old Wives Lake. 1960.

pelican is too unique a feature of the summer landscape to be allowed to disappear.

\section{LITERATURE CITED}

FERRY, JOHN F. 1910. Birds observed in Saskatchewan, summer of 1909. Auk, 27:185204.

MUNRO, J. A. 1929. Manito Lake-description of lake and bird life. Can. Field-Nat., 43: 100-103.

THOMPSON, BEN H. 1932. History and present status of the breedina colonies of the White Pelican. Occas. Paper \#1. National Park Service, U.S. Dept. Interior.

\section{PROTECTION URGED FOR COLONIAL BIRDS ON REDBERRY LAKE}

At a meeting of the Saskatoon Natural History Society on January 18,1962 a resolution was drafted urging protection of colonial birds on Redberry Lake. Learning of plans to turn Redberry Lake into a resort, the Society was particularly concerned lest nesting sites of pelicans, cormorants, gulls and terns on the islands in the lake be destroyed. Even though the lake is a wildlife sanctuary, holidayers are likely to visit the islands during the nesting season, unaware that even a short visit sometimes results in the deaths of hundreds of young birds. The pelican in particular has been deprived of most of its for- mer nesting sites in settled Saskatchewan.

The following resolution was submitted to the Saskatchewan Department of Natural Resources and the Canadian Wildlife Service:

Because pelicans, cormorants, gulls and terns are birds of very limited habitat, with specific nesting requiremnets, be it resolved that the islands of Redberry Lake and the waters within half a mile of the islands be preserved unmolested as a wildlife sanctuary.

In reply, the Honourable A. G. Kuziak, Minister of Natural Resources, told the Society that his department plans no recreation development for Redberry Lake in the immediate future. Should such development take place at a later date, Mr. Kiuziak assured the Society, "you may be certain that my department will be most concerned that the faunal life of the lake be safeguarded against disturbance and destruction of habitat."

While encouraged to learn that the Recreation Branch will not initiate development without considering the needs of colonial birds, the Society is still concerned about private plans for development of the lake. 